\title{
Synthesis and Characterization of N-Benzylidene Aniline Ligand for Spectrophotometric Determination of Nickel
}

\author{
James M. Okuo ${ }^{1}$ Emmanuel I. Chiedu ${ }^{2} \quad$ Bala Anegbe $^{3} \quad$ Faith O. Oyibo $^{1}$ \\ 1.Environmental Analytical Research Laboratory, Department of Chemistry, University of Benin, Benin City \\ 2.Department of Production, Analytical and Laboratory Management, Federal Institute of Industrial Research \\ Oshodi, Lagos State, Nigeria \\ 3.Department of Basic and Industrial Chemistry, Western Delta University, P.M.B. 10, Oghara, Delta State
}

\begin{abstract}
Schiff bases are compounds containing azomethine group $(-\mathrm{HC}=\mathrm{N}-)$. They are condensation products of ketones or aldehydes (aldehydes and ketones) with primary amines. Formation of Schiff base generally takes place under acid or base catalysis or with heat. The spectrophotometric determination of metals using Schiff base metal complex is very important in analytical chemistry. This study has helped to establish a novel, simple and cheap analytical method for the determination of nickel in an environmental sample especially in developing countries where the cost and maintenance of sophisticated instruments are extremely high. In this study, Schiff base ligand was synthesized using benzaldehyde and aniline to form a metal complex with the target analyte $\left(\mathrm{Ni}^{2+}\right)$. The melting point and electrical conductivity of the synthesized nickel complex were $175.6^{\circ} \mathrm{C}$ and $84 \times 10^{-6} \Omega^{-1} \mathrm{~cm}^{-}$ ${ }^{1}$ respectively and the maximum absorbance at $360 \mathrm{~nm}$ was 0.60 . The complex was characterized using different spectroscopic techniques. The peak in FT-IR spectra at $1625.2 \mathrm{~cm}^{-1}$ confirmed the $(\mathrm{C}=\mathrm{N})$ stretching vibration. The ${ }^{13} \mathrm{C}$ and ${ }^{1} \mathrm{H}$ NMR spectra showed 193.8 and $10.0 \mathrm{ppm}$ respectively of $(\mathrm{CH}=\mathrm{N})$ which was assigned to the azomethine carbon atom and the GC-MS analysis revealed a plausible structure of the complex. The stoichiometry of the Schiff base nickel (SB-Ni) complex was established as $\mathrm{NiSB}_{2}$ by Job's method of continuous variation, moleratio and slope-ratio methods. The three procedures are in agreement over the stoichiometry of the SB-Ni complex. Keywords: Complex, Stoichiometry, N-benzylideneaniline, Spectrophotometric, Ligand
\end{abstract}

DOI: $10.7176 / \mathrm{CMR} / 11-10-04$

Publication date: December $31^{\text {st }} 2019$

\section{INTRODUCTION}

The common Schiff bases are crystalline solids, which are feebly basic but at least some form insoluble salts with strong acids (Amit et al. 2014). Schiff bases are used as intermediates for the synthesis of amino acids or as ligands for preparation of metal complexes having a series of different structures and it is also formed typically by the condensation of a primary amine and an aldehyde/ketone (Annapoorani and Krishnan 2013). The resultant compound, $R_{1} R_{2} C=N R_{3}$ is called a Schiff base, where $R_{1}$ is an aryl group, $R_{2}$ is a hydrogen atom and $R_{3}$ is either an alkyl or aryl group. However, compounds where $\mathrm{R}_{3}$ is an alkyl or aromatic group are also regarded as Schiff bases (Archana 2013). Schiff bases that contain aryl substituent are substantially more stable and readily synthesized, while those which contain alkyl substituent are relatively unstable (Chaundhary 2013). Schiff bases generally are bi, tri, or tetra-dentate chelate ligands and form very stable complexes with metal ions. Their chemical and physical properties in various fields such as preparative uses, identification, or protection and determination of aldehyde or ketones, purification of carbonyl and amino compounds or production of these compounds in complex or sensitive reactions have been studied by various researchers (Garima and Jyoti 2015; Consiglio et al. 2012; Badekar et al. 2016). Schiff bases are also known as anils, imines or azomethines and several studies showed that the presence of a lone pair of electrons in $\mathrm{sp}^{2}$ hybridized orbital of nitrogen atom of the azomethine group is of considerable chemical and biological importance (Katwal et al. 2013; Chandraleka et al. 2011; Anita and Manish 2013). Due to the relative easiness of preparation, synthetic flexibility, and the special property of $\mathrm{C}=\mathrm{N}$ group, Schiff bases are generally excellent chelating agents, especially when a functional group like $-\mathrm{OH}$ or $-\mathrm{SH}$ is present close to the azomethine group so as to form a five or six membered ring with a metal ion. Versatility of Schiff base ligands and biological, analytical and industrial applications of their complexes make further investigations in this area highly desirable (Anand et al. 2012; Al-Resayes et al. 2011; Okolo and Okuo 2003; Skoog et al. 2007). Nickel is one of the ubiquitous elements and ranks 23 in order of abundance. Its average concentration in the earth's crust is $75 \mathrm{mg} / \mathrm{kg}$. Nickel is relatively toxic and widespread in the environment. Nickel enters the environment through two main pathways: natural- such as weathering of minerals, rocks and geochemical emission, and anthropogenic such as industrial and vehicular emissions (Manno et al. 2006). Nickel particles in the air settle to the ground or are taken out of the air in rain. Much of the nickel in the environment is found in soil and sediments because nickel attaches to particles that contain iron or manganese, which are often present in soil and sediments (Mtunzi et al. 2015). It is considered as a borderline element between hard and soft acid acceptors in chemical interactions towards donor atoms. Nickel salts are soluble and can occur as a leachate from nickel bearing rocks. The effects of nickel exposure vary from skin irritation to damage to 
lungs, the nervous system, and mucous membranes. It is also a known carcinogen (Singh et al. 2012).

The objectives of this study are: 1. Synthesis of Schiff base ligand from benzaldehyde and aniline followed by synthesis of nickel (Ni) complex using the ligand as a complexing agent. 2. Characterization of the synthesized ligand and its $\mathrm{Ni}$ complex using nuclear magnetic resonance (NMR), melting point determination, electrical conductivity, IR, AAS, GC-MS and UV-VIS spectroscopic techniques. 3. Establishing the stoichiometry of the SB-Ni complex using mole-ratio, slope-ratio and job's method of continuous variation. 4 . Determination of the accuracy and precision of the proposed method. 5. Applying and comparing the new method with a known method of $\mathrm{Ni}$ determination such as atomic absorption spectroscopy (AAS).

\section{MATHERIALS AND METHODS}

\subsection{Materials}

Brucker Advance Neo III (400 Hz) Nuclear Magnetic Resonance (NMR) Spectrophotometer Schimadzu AAS Analyst 7000, Agilent Technology FT-IR Spectrophotometer, Jenway 3020 pH meter, Gynesis 90 thermoscientificUV/Vis-spectrophotometer, AR 2130OhausCoporation analytical balance; Brucker FT-IR Spec, Magnetic stirrer: Stuart heat-stir hot plate SD162, Agilent Technology 7890 GC-MS, Volumetric (calibrated) flasks, beakers and conical flasks. All reagents used were of analytical grade: $\mathrm{HCl}, \mathrm{NiCl}_{2} \cdot 6 \mathrm{H}_{2} \mathrm{O}, \mathrm{HNO}_{3}, \mathrm{NaOH}$, DMSO, aniline, methylamine, benzaldehyde, 95\% ethanol, petroleum ether, methanol and distilled water.

\subsection{Methods}

\subsubsection{Preparation of N-benzilideneaniline Ligand}

Equimolar quantity of benzaldehyde $10.143 \mathrm{ml}(1.025 \mathrm{mmol})$ and aniline $9.099 \mathrm{ml}(1.010 \mathrm{mmol})$ were mixed with rapid stirring in a $250 \mathrm{ml}$ round bottom flask provided with a stirring bar, thermometer and reflux condenser for 2 minutes. The reaction began after five seconds followed by evolution of heat and separation of water. The mixture was allowed to reflux at $80^{\circ} \mathrm{C}$ for four hours and then poured with fast stirring into a $600 \mathrm{ml}$ beaker containing $16.5 \mathrm{ml}$ absolute ethanol. Crystallization of the product was achieved by allowing the mixture to further stand in an ice bath for 30 minutes. Solid mass of the product, N-benzilideneaniline was quantitatively transferred to a filter paper and allowed to dry in a desiccator using activated silica gel for 48 hours. $83.986 \%$ product yield was obtained and the melting point was found to be $56.2^{\circ} \mathrm{C}$.

\subsubsection{Synthesis of Metal Complex}

The nickel metal complex of N-benzilideneaniline ligand was prepared by dissolving $2.377 \mathrm{~g}$ of 0.01 mole of $\mathrm{NiCl}_{2} .6 \mathrm{H}_{2} \mathrm{O}$ in $5 \mathrm{ml}$ dry methanol in a $100 \mathrm{ml}$ round bottom flask. $3.625 \mathrm{~g}$ of 0.02 mole of the synthesized $\mathrm{N}$ benzilideneaniline ligand was dissolved in $10 \mathrm{ml}$ of methanol in a separate $100 \mathrm{ml}$ round bottom flask. The methanolic solution of the metal chloride and the ligand were mixed and refluxed in a $250 \mathrm{ml}$ round bottom flask provided with a magnetic stirrer, thermometer and reflux condenser. Refluxing was continued for six hours at $80^{\circ} \mathrm{C}$ under constant stirring. Finally, the solution was allowed to cool for 24 hours and $10 \mathrm{ml}$ of ethanol was added. A colored complex was separated out, filtered, washed with petroleum ether and dried under desiccator using activated silica gel. The purity of the complex was checked by thin layer chromatography (TLC).

\subsubsection{Determination of Optimum pH of SB-Ni Complex}

The optimum $\mathrm{pH}$ of SB-Ni complex was determined using the method of Okoye et al. (2013). Reaction mixtures each containing $4.0 \mathrm{ppm} \mathrm{Ni}{ }^{2+}$ and $0.72 \%(\mathrm{~m} / \mathrm{v})$ which is the optimum concentration of SB-Ni complex obtained from the maximum absorbance of the $\mathrm{SB}$ along with $3 \mathrm{ml} 0.5 \mathrm{M} \mathrm{NaOH}$ and $3 \mathrm{ml}$ methylamine were prepared in twenty-one separate $25-\mathrm{ml}$ calibrated flasks. Each was adjusted to a given $\mathrm{pH}$ ranging from 3 to 13 , using $1.0 \mathrm{M}$ $\mathrm{NaOH}$. The absorbance of each solution was taken at $360 \mathrm{~nm}$. A plot of absorbance vs $\mathrm{pH}$ was made.

2.2.4 Determination of Wavelength of Maximum Absorption ( $\lambda$ max) of Schiff Base Nickel (SB-Ni) Complex The absorption spectra of the SB-Ni complex at $\mathrm{pH} 12.50$ were investigated using the methods of Okolo and Okuo. (2003). At 4.0ppm Ni ${ }^{2+}$ ion concentration, the solution was treated with the reaction mixture ( $\left.\mathrm{Rm}\right)[5 \mathrm{ml} 3 \% \mathrm{SB}$, $3 \mathrm{ml} 0.50 \mathrm{M} \mathrm{NaOH}$ and $3 \mathrm{ml}$ methylamine] and made up to $25 \mathrm{ml}$ final solution with distilled water in a standard flask [reaction mixture $(\mathrm{Rm})$ ]. A reagent blank $(\mathrm{Rb})$, which was the reaction mixture without the analyte $\left(\mathrm{Ni}^{2+}\right)$ was also prepared.

The wavelength of maximum absorption ( $\lambda$ max) of the Rm and $\mathrm{Rb}$ was established by scanning from 190 to $570 \mathrm{~nm}$ in $1 \mathrm{~cm}$ matched silica cells using Gynesis 90 thermoscientific UV/Vis- spectrophotometer.

\subsubsection{Determination of Schiff Base Concentration on the Absorbance of the SB-Ni Complex}

Investigation of the variation of absorbance of SB-Ni complex with SB concentration was carried out by measuring the absorbance of the usual reaction mixture solutions containing 4.0ppm of $\mathrm{Ni}^{2+}$ with varying amounts of $\mathrm{SB}$ at $360 \mathrm{~nm}$ and $\mathrm{pH} 12.50$. The absorbance was plotted against SB concentrations (\%m/v) (Okolo and Okuo 2003).

\subsubsection{Effect of Reaction Time}

This determines the maximum time required for maximum colour development in the SB-Ni system. The absorbance of the Rm vs $\mathrm{Rb}$ was taken at 5-minute interval at $360 \mathrm{~nm}$ and $\mathrm{pH} 12.50$ in matched 1-cm silica cells (Garima and Jyoti 2015). 


\subsubsection{Determination of the stability of $\mathbf{R m}$ and $\mathbf{R b}$ )}

To determine the stability of the $\mathrm{Rm}$ and $\mathrm{Rb}$ after maximum colour had been developed at optimum $\mathrm{pH} 12.50$. The $\mathrm{Rm}$ and $\mathrm{Rb}$ were prepared and allowed to stand for 20 minutes for maximum colour development, The $\mathrm{pH}$ was adjusted to 12.50 and the absorbance readings were taken at 30 -minute interval at $360 \mathrm{~nm}$ in matched $1-\mathrm{cm}$ silica cells (Gononka et al. 2015).

2.2.8 Order of Addition of Reagent

$0.72 \%(\mathrm{~m} / \mathrm{v}) \mathrm{SB}, \mathrm{Ni}^{2+}$ concentration of $4.0 \mathrm{ppm}, 3.0 \mathrm{ml}$ of $0.5 \mathrm{M} \mathrm{NaOH}$, and $3.0 \mathrm{ml}$ of methylamine were mixed in a $25 \mathrm{ml}$ volumetric flask in the order of $\mathrm{a}+\mathrm{b}+\mathrm{c}+\mathrm{d}$ and made up to mark with distilled water. This was allowed to stand for 20 minutes for max colour development, and then adjusted to $\mathrm{pH} 12.50$. Absorbance reading of the solution was taken at $360 \mathrm{~nm}$ in a matched $1 \mathrm{~cm}$ silica cells. The order of addition of reagents was varied Twenty four times to obtain the optimum order, using permutation principles $\left({ }^{4} \mathrm{P}_{4}\right)$ (Ekoko, 2014).

2.2.9 Adherence to Beer's Law

$\mathrm{Ni}^{2+}$ concentration range of $0.5-6.0 \mathrm{ppm}$ and the $\mathrm{Rm}$, were placed in a $25 \mathrm{ml}$ volumetric flasks, and made up to mark with distilled water. The reaction mixture $(\mathrm{Rm})$ was allowed to stand for 20 minutes. The $\mathrm{pH}$ was adjusted to 12.50 with $1.0 \mathrm{M} \mathrm{NaOH}$. The absorbance reading of each $\mathrm{Rm}$ was taken at $360 \mathrm{~nm}$, at ambient temperature, 25 $30^{\circ} \mathrm{C}$ (Okolo and Okuo 2003). A plot of absorbance vsanalyte concentration was made.

\subsubsection{Stoichiometric Determination}

Several methods can be used to determine the ratio of the ligand to the metal in a complex (Manno et al. 2006). In this study, Job's method of continuous variation, mole ratio and slope ratio methods were used to complement one another.

\subsubsection{Interference Studies}

The possible interfering effects of foreign ions on the analytical signal of $4.0 \mathrm{ppm} \mathrm{Ni}{ }^{2+}$ were studied using a similar procedure of Okolo and Okuo (2003). Some of the ions chosen are constituents of major components of natural waters while others are those that form ion-associated complexes with $\mathrm{Ni}^{2+}$ e.g. $\mathrm{Ag}+, \mathrm{NO}_{3}{ }^{-}, \mathrm{Ca}^{2+}, \mathrm{Zn}^{2+}, \mathrm{SO}_{4}{ }^{2-}$ etc. The criterion for the interference was fixed at $\pm 5.0 \%$ thus concentration of foreign ions which caused relative deviation in absorbance equal to or lower than $5.0 \%$ were tolerated.

Three samples were prepared: reference sample (Rs), test sample (Ts) and reagent blank (Rb). The reference sample (Rs) was the reaction mixture (Rm) containing $4.0 \mathrm{ppm} \mathrm{Ni}^{2+}$, the test sample (Ts) was the reaction mixture plus the interference, while the reagent blank was the reaction mixture without the analyle. The Rs, Ts and $\mathrm{Rb}$ were allowed to stand for 20 minutes and $\mathrm{pH}$ adjusted to 12.5 . The absorbance (A) readings were taken at $360 \mathrm{~nm}$. The relative deviation due to the interference was calculated using the relation:

Relative deviation $=\frac{\text { Absorbance without interference-Absorbance with interference }}{\text { Absorbance without interference }} \times 100$

\subsubsection{Recovery Tests on SB-Ni Complex}

This test estimates the fraction of the analyte (Ni) obtained after a standard solution of the analyte has been analysed using the proposed method. It established the effectiveness (precision and accuracy) of the method. Distilled - deionized water samples were spiked with known amounts of nickel [0 to $6.0 \mathrm{ppm}(\mu \mathrm{g} / \mathrm{ml})] \mathrm{each}$ contained $0.72 \%(\mathrm{~m} / \mathrm{v}) \mathrm{SB}, 3 \mathrm{ml}$ of $0.5 \mathrm{M} \mathrm{NaOH}$ and $3.0 \mathrm{ml}$ of methylamine $(\mathrm{Rm})$ and all made up to final volume of $25.0 \mathrm{ml}$ with distilled-deionized water. The solution was allowed to stand for 20 minutes for maximum colour development before adjusting their $\mathrm{pH}$ to 12.5 with $1.0 \mathrm{M} \mathrm{NaOH}$. The absorbance was taken at $360 \mathrm{~nm}$ in $1-\mathrm{cm}$ matched silica cells against the reagent blank.

Following the procedure of Okolo and Okuo (2003), a calibration curve was prepared to cover $\mathrm{Ni}^{2+}$ concentration range $0-6.00 \mathrm{ppm}$. From the calibration curve, the $\mathrm{Ni}^{2+}$ concentration in each $25.0 \mathrm{ml}$ final volume was determined in five replicates. The standard deviation (SD), relative standard deviation (RSD), and $95 \%$ confidence limit were calculated using the method of Okolo and Okuo (2003).

2.2.13 Limit of detection (LOD), limit of quantitation (LOQ), and method sensitivity (MS)

The LOD and LOQ were estimated from 10 replicate reaction mixtures, each containing $0.05 \mu \mathrm{g} / \mathrm{ml} \mathrm{Ni}^{2+}$, while the MS was determined from figure 3.12. These were the minimum concentration of the analyte that gave an analytical signal based on this method (Raman et al. 2009).

\section{RESULTS AND DISCUSSION}

\subsection{Physico-chemicacharacterization of N-benzylideneaniline Ligand and Metal Complex}

The complex was air-stable with high melting point and was soluble in methanol, chloroform, diethylether, ethanol and dimethylsulphoxide (DMSO). Table 3.1 summarizes the physical characteristics of the ligand and its metal complex. 
Table3.1Physico-chemical Characterization of N-benzylideneaniline and its Metal Complex

\begin{tabular}{llllll|l}
\hline Variables & Colour & Melting point & IR $(\mathrm{C}=\mathrm{N})$ & ${ }^{1} \mathrm{CNMR}(\mathrm{CH}=\mathrm{N})$ & ${ }^{1} \mathrm{H}(\mathrm{CH}=\mathrm{N})$ & \\
\hline Literature Value & Olive green & $176.1^{0} \mathrm{C}$ & 1627.0 & 194.0 & 9.9 & \\
Experimental Value & Olive green & $175.6^{0} \mathrm{C}$ & 1625.2 & 193.8 & 10.0 & \\
\hline
\end{tabular}

3.1.1 Measurement of Electrical Conductivity

The electrical conductance measurement was done to ascertain the anions of the metal complex remain inside or outside the coordination sphere of the central metal atom.

The specific conductance of the synthesized $\mathrm{Ni}^{2+}$ complex $\left(\mathrm{Ni}^{2+}=26.87 \Omega^{-1}\right)$ was $84 \times 10^{-6} \Omega^{-1} \mathrm{~cm}^{-1}$. The conductance of $0.2 \mathrm{M} \mathrm{KCl}$ used was $849 \Omega^{-1}$. This was used to calculate the cell constant which gave $2.9 \times 10^{-6} \mathrm{~cm}^{-}$ 1. The high value of the molar conductance suggests that the complex behaves like an electrolyte.

\subsubsection{UV-Visible Spectra}

The UV-visible spectra of the Schiff base complex recorded in DMSO solvent with the wavelength range of 900$200 \mathrm{~nm}$ at room temperature showed two absorption bands of 375.909 and $386.434 \mathrm{~nm}$. These two absorption bands in the electronic spectrum of the ligand could be assigned to $n-\pi^{*}$ and $\pi-\pi^{*}$ transition. These transitions are also found in the spectra of complexes, but they appeared to be shifted towards lower and higher frequencies, confirming the coordination of ligands to metal ion.

\subsubsection{FT-IR Spectra}

The infra-red (IR) spectra of the N-benzylidene aniline (Schiff base) ligand shown in Figure 3.1 shows stretching and out-of-plane bending vibration for $\left(\mathrm{sp}^{2}=\mathrm{C}-\mathrm{H}\right)$ at 3059.50 and $689.92 \mathrm{~cm}^{-1}$ respectively. This indicates the presence of aromatic ring in the Schiff base ligand. This extremely intense absorption of out-of-plane C-H bending vibration resulting from strong coupling with adjacent hydrogen atom, explains the presence of monosubstituted alkyl-(methyl group) attached to the aromatic ring (Ar-CH). The methyl hydrogen furnishes only one weak $\mathrm{C}-\mathrm{H}$ stretching at $2889.4 \mathrm{~cm}^{-1}$. The N-benzylidene free ligand also shows stretching vibration of the azomethine nitrogen with the aromatic ring at $1191.22 \mathrm{~cm}^{-1}(\mathrm{Ar}-\mathrm{N})$ in the spectrum. The IR spectra of the complex show the coordination sites that may be involved in the chelation (Figure 3.2). There were some guide peaks in the spectra of the ligand which were helpful in achieving the result. The position and/or the intensities of the peaks were expected to change upon chelation.

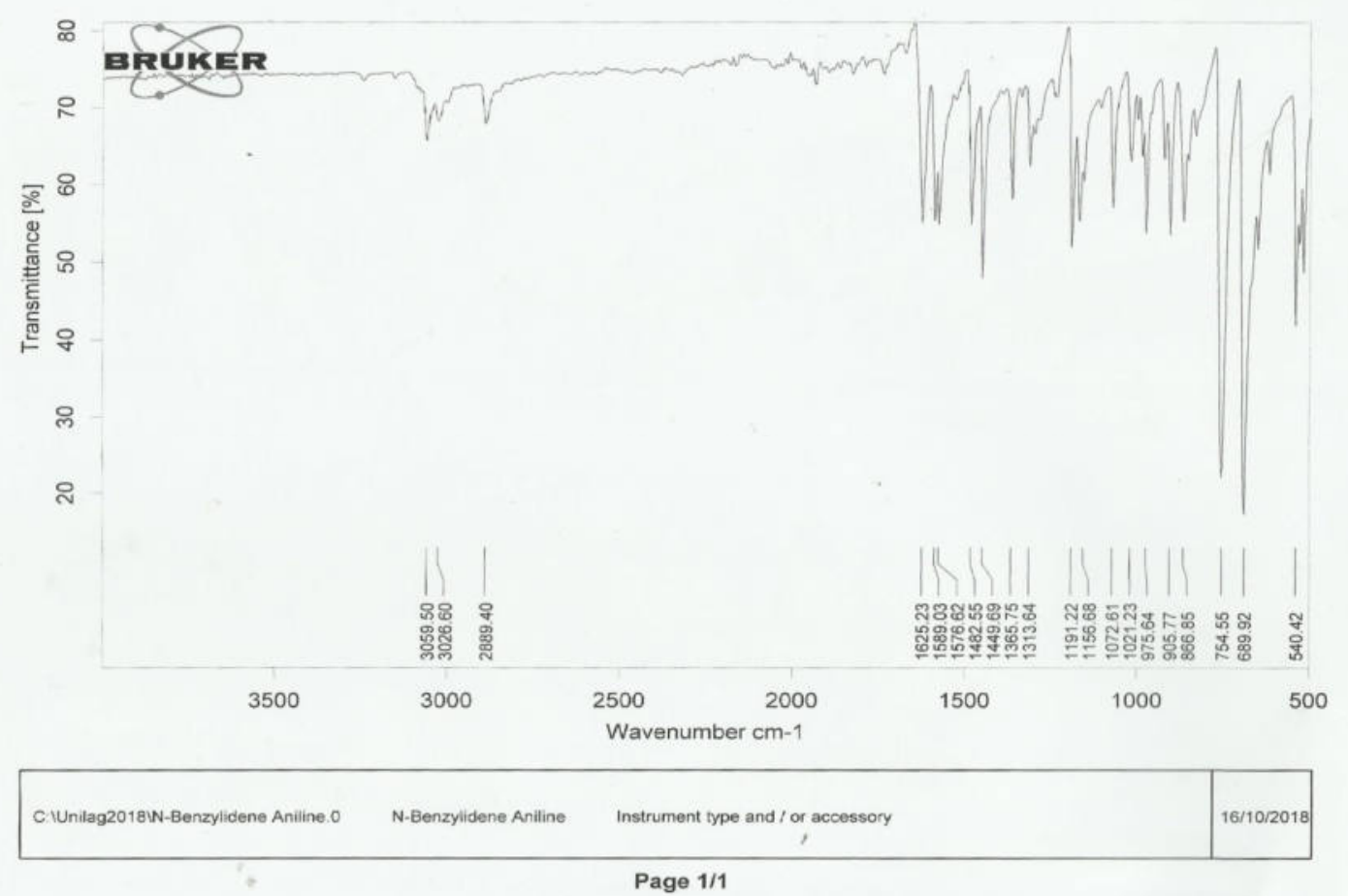

Figure 3.1 FT-IR Spectra and Mode of Vibrational Frequencies of Schiff Base Ligand 


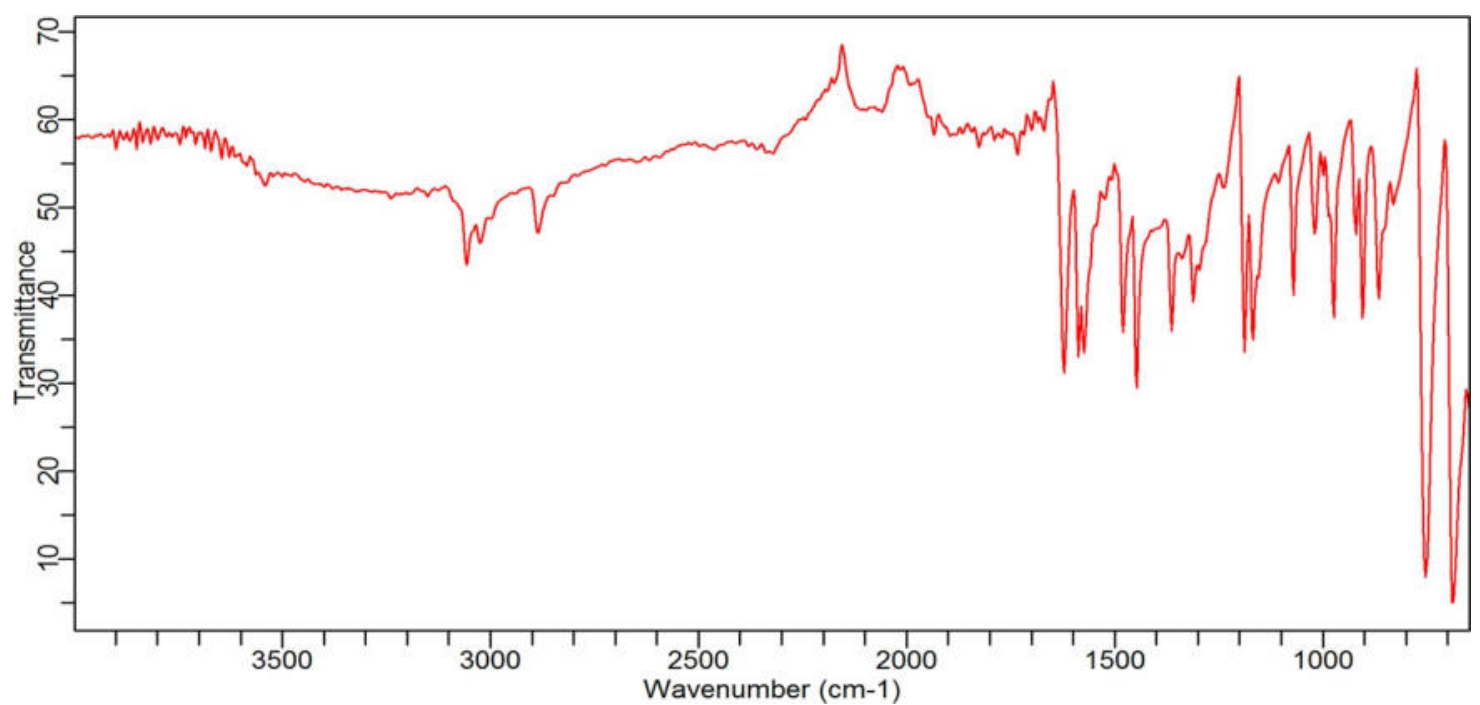

Figure3.2 FT-IR Spectra and Mode of Vibrational Frequencies of Schiff Base-Nickel Complex

3.1.4 Nuclear Magnetic Resonance (NMR) Spectroscopy of Schiff Base-Nickel Complex

Nuclear magnetic resonance spectroscopy was conducted to determine the plausible structure of $\mathrm{N}$ benzylideneaniline nickel complex.

3.1.4.1Carbon $13\left({ }^{13} \mathrm{C}\right) \mathrm{NMR}$

The ${ }^{13} \mathrm{C}$ spectra recorded on dimethyl sulphoxide (DMSO) in Figure 3.3showed a signal which appeared at $\delta$ $193.670 \mathrm{ppm}$ and was assigned to the azomethine carbon atom $(\mathrm{CH}=\mathrm{N})$. The chemically nonequivalent aromatic ring carbon atom of the ligand furnished resonance peaks at chemical shift of 116.2032, 126.4297, 129.1367, $129.2748,129.6608,129.9444,131.9332,135.0332,136.4846,136.6676,151.9367,161.1494$ ppm and quaternary carbon atoms which were parts of the rings and adjacent to the azomethine carbon and nitrogen as well, provided low intensity signals at $ð$ of 136.4846 and $151.9367 \mathrm{ppm}$. Trace of phenylamine droplets which were found in the ligand shows peaks at $114.4172,121.4172,121.4309$ and $129.6170 \mathrm{ppm}$.

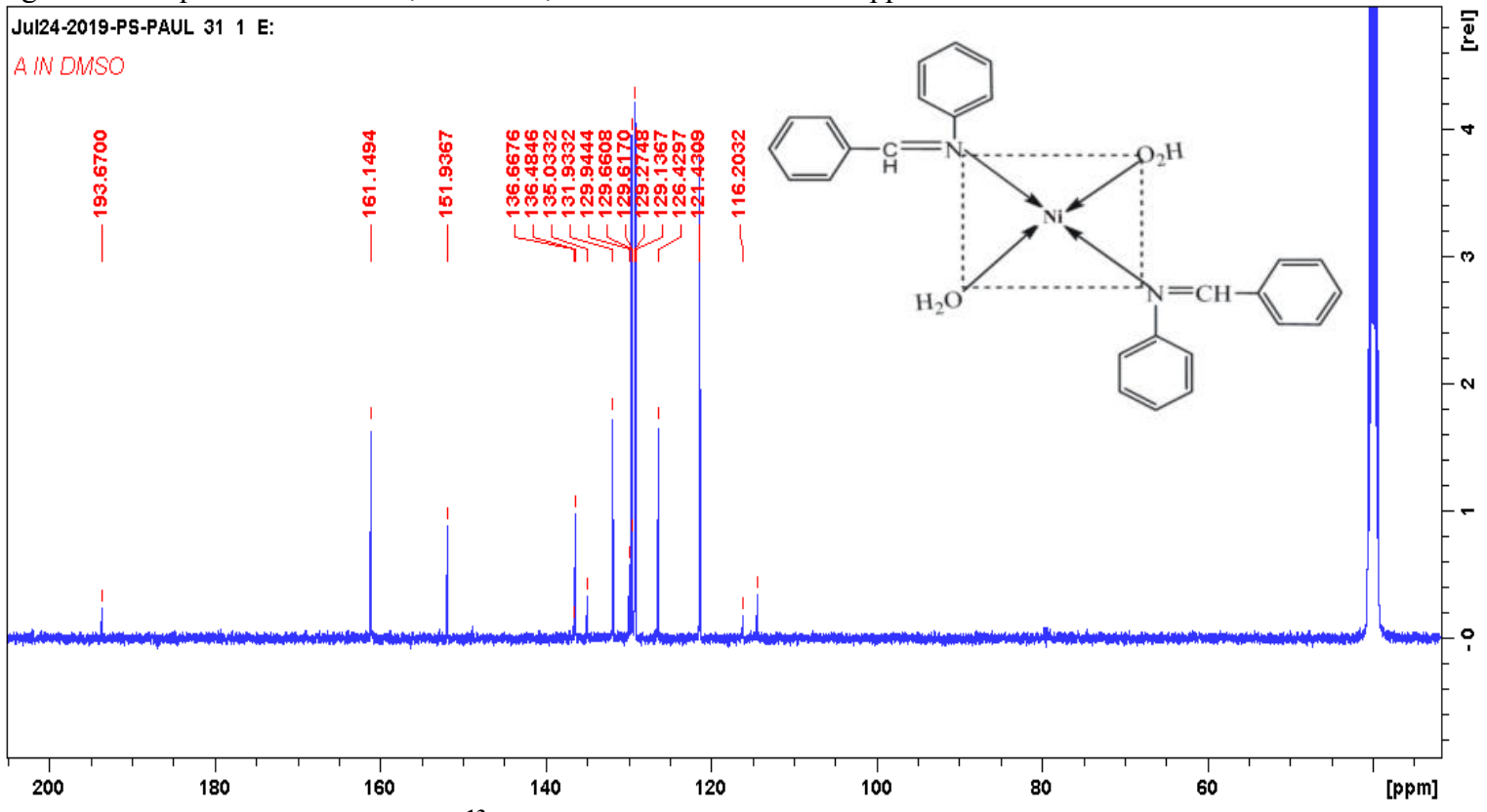

\subsubsection{Proton $\left({ }^{1} \mathrm{H}\right)$ NMR}

Figure 3.3 ${ }^{13} \mathrm{C}$ NMR Spectra of Schiff Base-Nickel Complex

The Schiff base (SB) proton NMR in Figure 3.4 shows highly de-shielded singlet absorption at $ð$ (10.0183 ppm $1 \mathrm{H})$ which can be attributed to the azomethine proton $(\mathrm{HC}=\mathrm{N}-)$. The region of $ð(6.4941-8.6123 \mathrm{ppm}, 10 \mathrm{H})$ with multiple signal absorption were assigned to chemically nonequivalent aromatic protons (Ar-H). The strong signal which appeared at ठ $3.3389 \mathrm{ppm}$ can be attributed to unreacted or excess droplets of phenyl amine protons during ligand synthesis. Dimethyl sulphoxide (DMSO) used as solvent was not $100 \%$ isotopically pure and contains some 
trace of DMSO- $\left(\mathrm{CH}_{3}\right)_{6}$ which gave a peak at $2.4983 \mathrm{ppm}$.

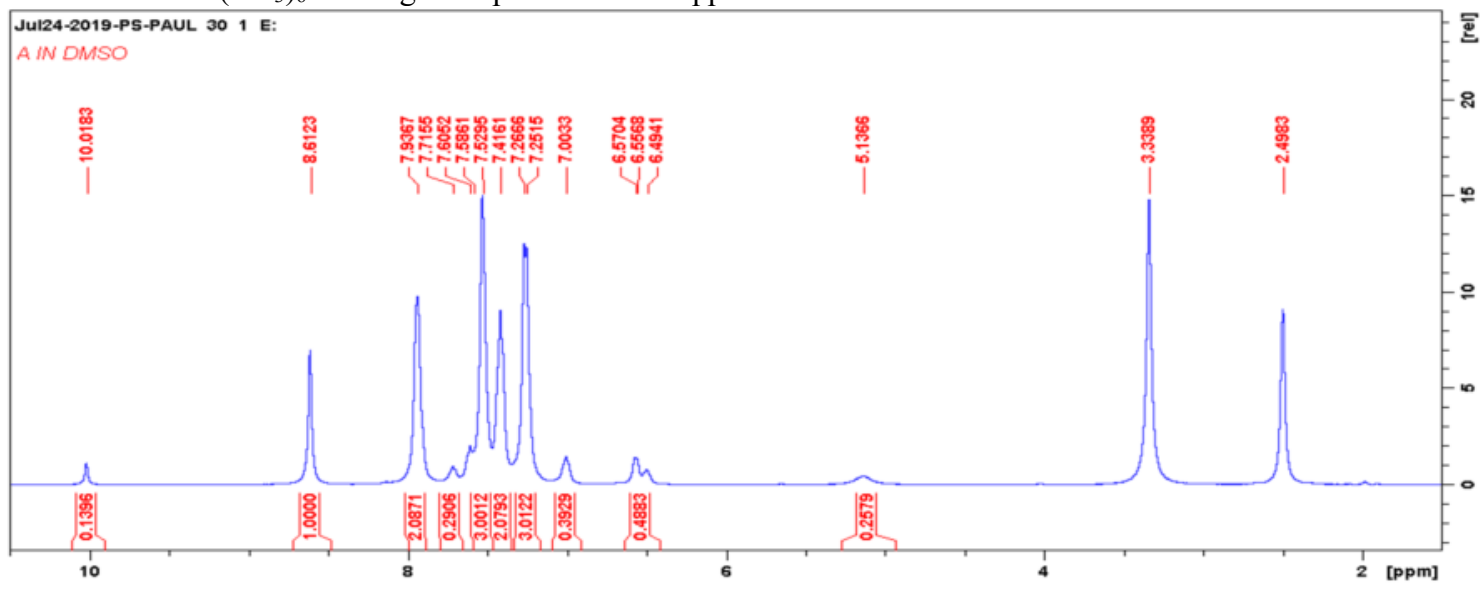

\subsubsection{GC-MS Scan}

Figure $3.4{ }^{1} \mathrm{H}$ NMR Spectra of Schiff Base-Nickel Complex

The GC-MS scan shown in Figure 3.5 explains the analysis of N-benzylideneaniline nickel complex in chloroform using helium as the carrier gas. The oven temperature program was $80^{\circ} \mathrm{C}$ to hold for two minutes at ten degrees per minute to a final temperature of $240^{\circ} \mathrm{C}$ to hold for ten minutes. The volume of sample injected was $1 \mu \mathrm{L}$, the scan range is from 50 to $550 \mathrm{amu}$. The mass spectrum of the component identified was compared with the spectrum of the known component stored in the National Institute of Standard and Technology (NIST) library and the name, molecular weight and the structure of the test sample was ascertained as represented on the chromatogram.

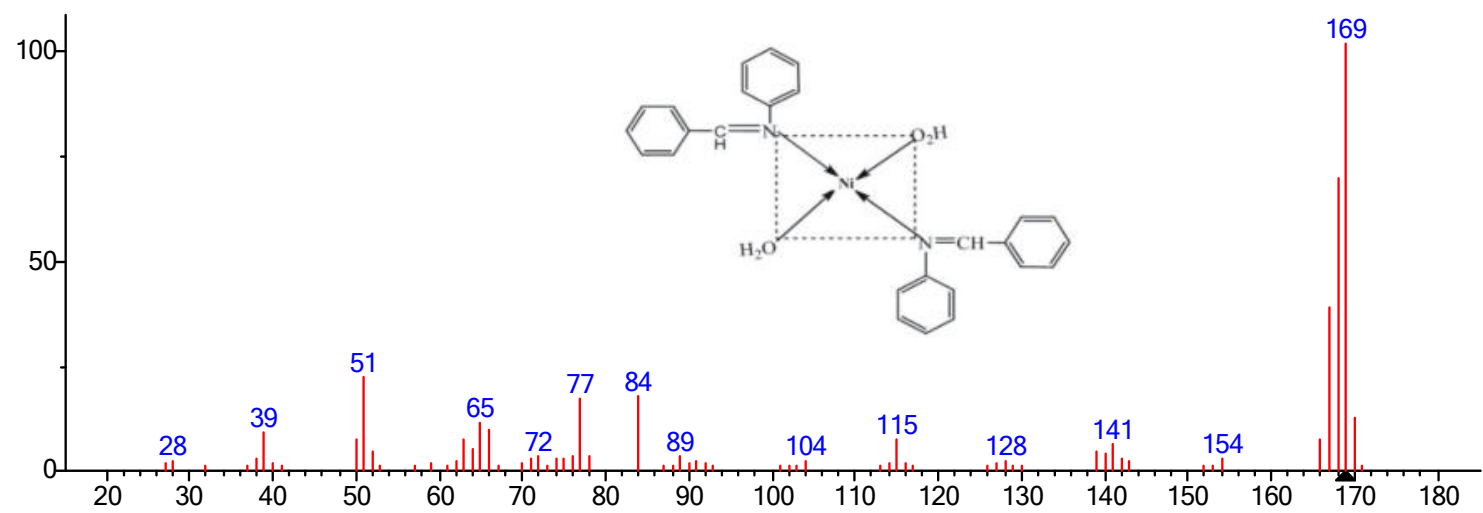

(mainlib) Diphenylamine

Figure 3.5 GC-MS Scan of Schiff Base-Nickel Complex

\subsubsection{Determination of Optimum pH of the SB-Ni Method}

Considering the $\mathrm{Ni}^{2+}$ and $\mathrm{SB}$ concentrations of $4.0 \mathrm{ppm}$ and $0.72 \%(\mathrm{~m} / \mathrm{v})$ respectively, and at $\lambda \max$ of $360 \mathrm{~nm}$, the variation of absorbance with $\mathrm{pH}$ is shown in Figure 3.8. These absorbance values showed prominent peaks at $0.391,0.586$ and 0.989 , corresponding to the $\mathrm{pH}$ of $6.5,8.5$ and 12.5, respectively. Further investigations revealed that at both $\mathrm{pH} 6.5$ and 8.5 , the $\mathrm{Rm}$ and $\mathrm{Rb}$ were unstable, while the $\mathrm{Rm}$ and $\mathrm{Rb}$ at $\mathrm{pH}$ value of 12.5 were far more stable. Therefore, $\mathrm{pH}$ value of 12.5 was chosen as the optimum $\mathrm{pH}$ for this method. 


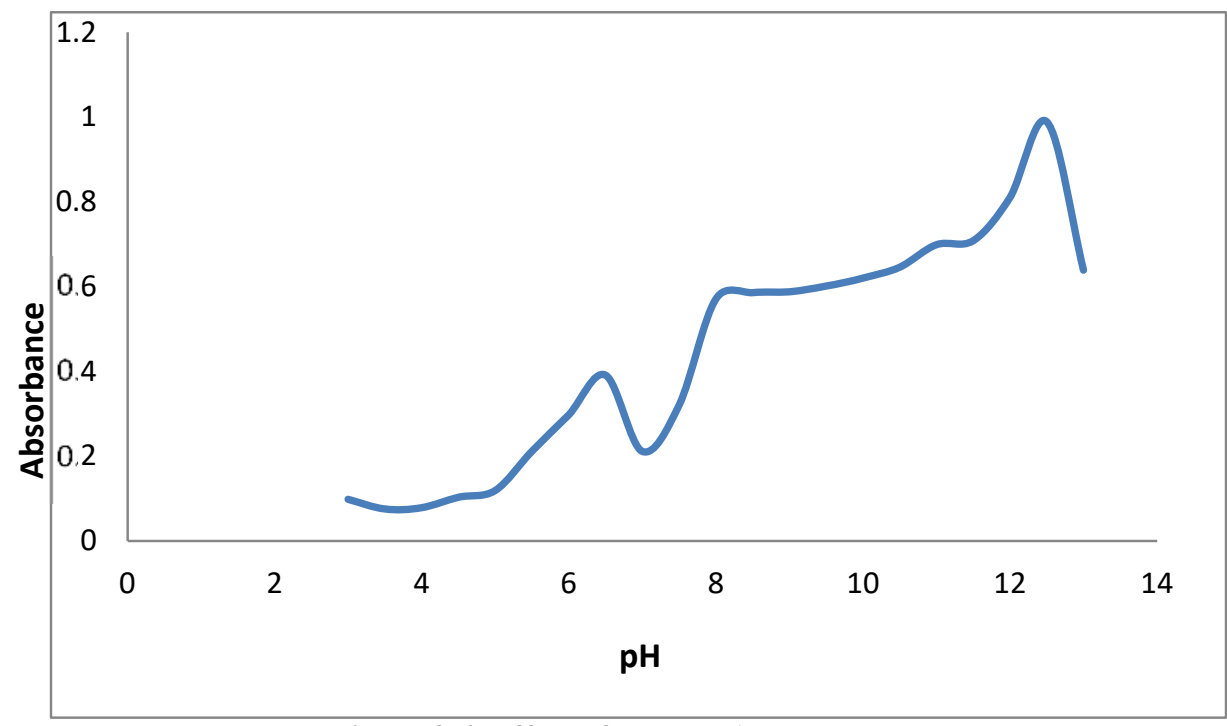

Figure 3.6 Effect of pH and Absorbance

3.1.7 Determination of Wavelength of Maximum Absorption ( $\lambda$ max) for SB-Ni Complex

Figure 3.6 shows the maximum absorbance for the SB-Ni complex and the reagent blank (Rb) at 0.60 and the corresponding wavelength $(\lambda \max )$ is at $360 \mathrm{~nm}$. For the $(\mathrm{Rb})$ and water, the maximum absorbance is about 0.01 which is far below the 0.60 for SB-Ni complex. This indicates that the $\mathrm{Rb}$ does not interfere with the absorbance due to the analyte.

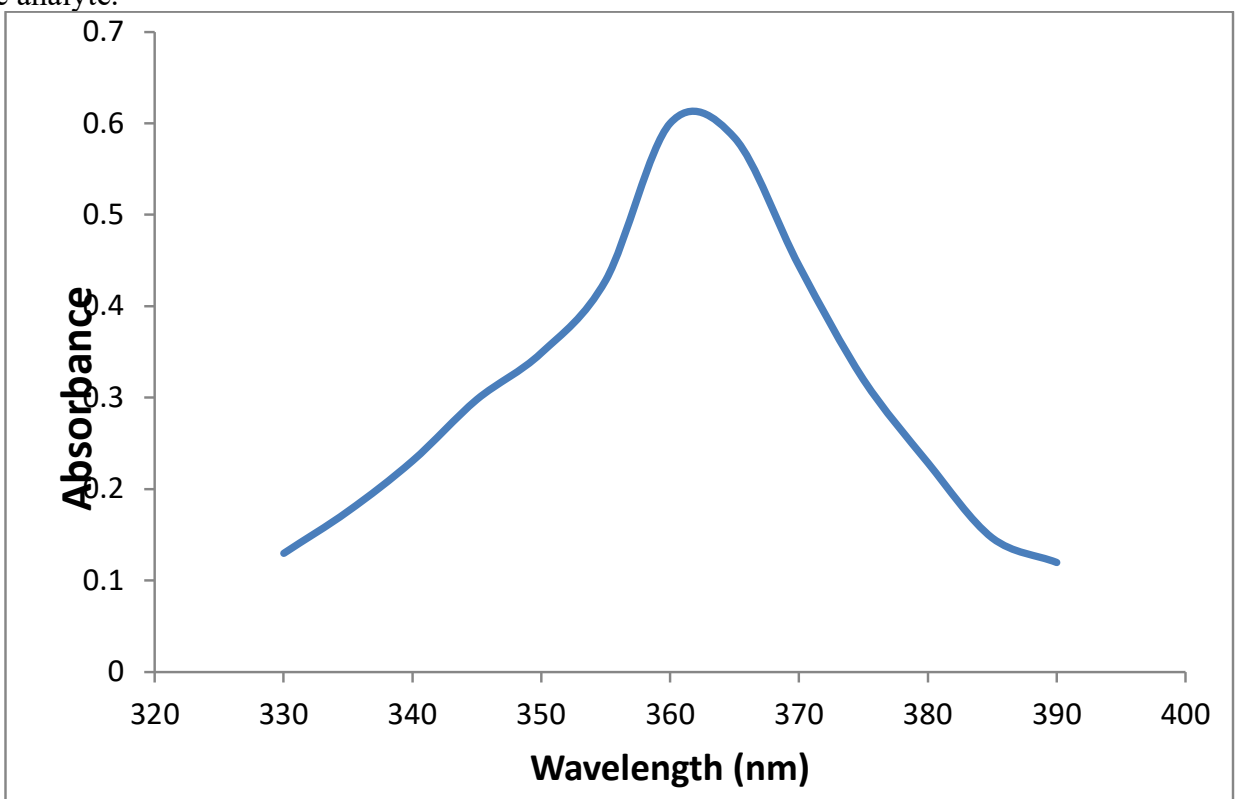

Figure 3.7 Determination of the wavelength of maximum absorption $(\lambda \max )$ 3.1.8 Effect of SB Concentration on the Absorbance of SB-Ni Complex

The effect of the SB concentration on the absorbance of SB-Ni complex is shown in Figure $3.7 \mathrm{At} 4.0 \mathrm{ppm} \mathrm{Ni}^{2+}$ concentration and varied concentrations of SB from 0.022 to $1.060 \%(\mathrm{~m} / \mathrm{v})$, the absorbance increased from 0.110 to a peak of 0.231 and then decreased steadily to 0.051 . The SB concentration of $0.720 \%(\mathrm{~m} / \mathrm{v})[6.0 \mathrm{ml}$ of $3 \%$ $(\mathrm{m} / \mathrm{v}) \mathrm{SB}$ solution in $25 \mathrm{ml}$ final volume] was therefore chosen as the optimum concentration for the SB-Ni method. 


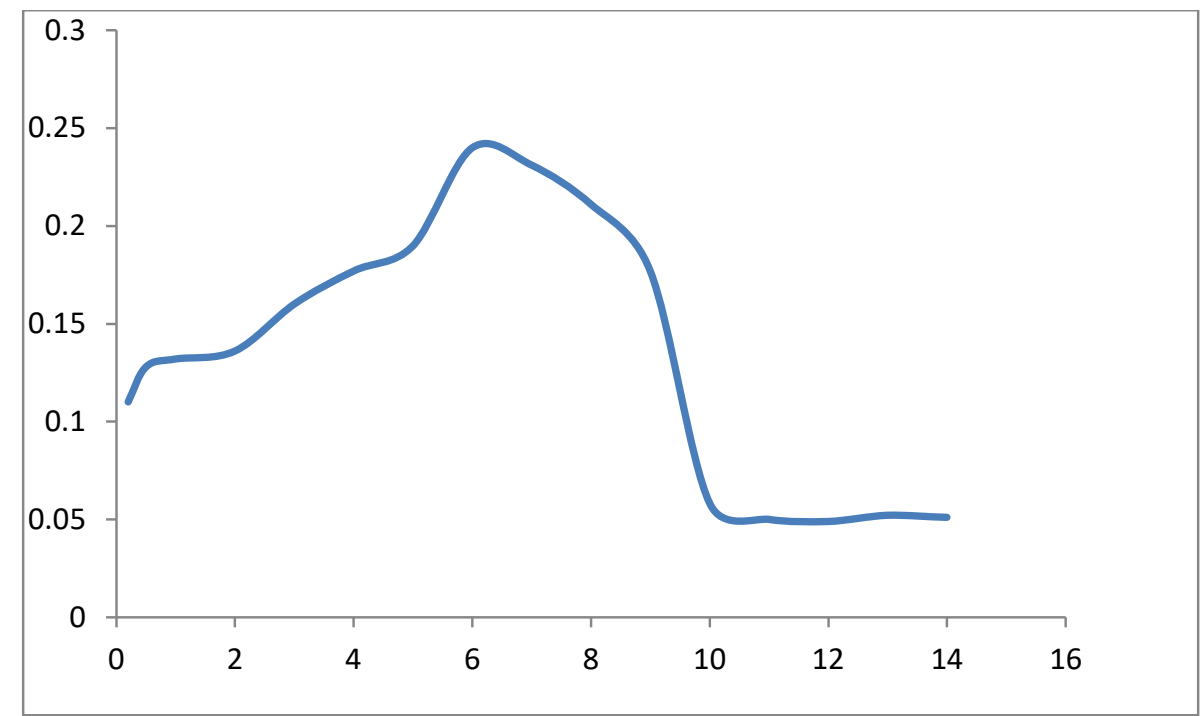

Figure 3.8: Effect of the SB Concentration on the SB-Ni system

\subsubsection{Effect of Reaction Time on Absorbance of SB-Ni System}

Figure 3.10 indicates that colour developed instantaneously on addition of methylamine to the reaction mixture. The absorbance reached a maximum after 20 minutes. Therefore 20 minutes was chosen for the maximum colour development of the reaction mixture $(\mathrm{Rm})$.

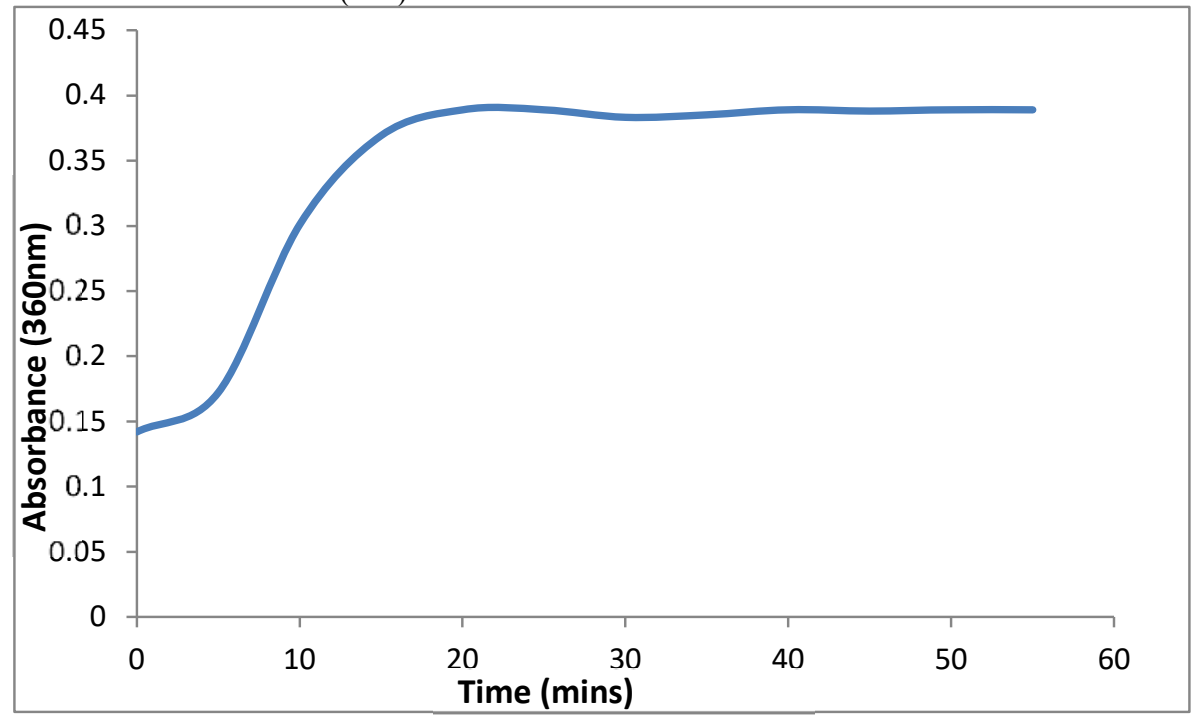

Figure 3.9 Effect of Reaction Time

3.1.10 Stability of the Reaction Mixture (Rm) and Reagent Blank (Rb)

Figure 3.10 above showed that colour developed instantaneously after addition of methylamine during the formation of the SB-Ni complex and reached a maximum after 20 minutes. Figure 3.11 reveals that after attainment of maximum colour development followed by $\mathrm{pH}$ adjustment to 12.5 , the absorbance of $\mathrm{Rm}$ and $\mathrm{Rb}$ remained constant for 80 minutes. After 80 minutes, absorbance decreased gradually. From the foregoing, therefore, it is recommended that once the maximum colour is attained and $\mathrm{pH}$ adjusted to 12.5 , the $\mathrm{Rm}$ and $\mathrm{Rb}$ were used within the next 1 hr 20 minutes ( 80 minutes). Thereafter the $\mathrm{Rb}$ and $\mathrm{Rm}$ were discarded. 


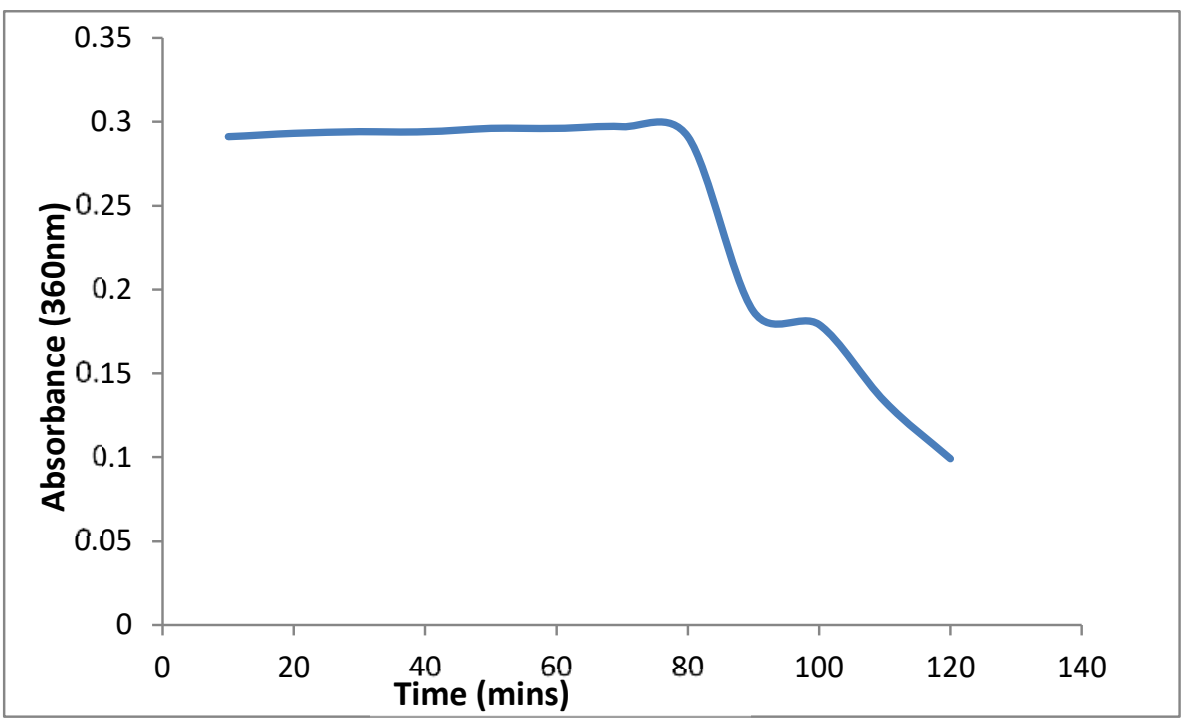

Figure 3.10: Stability of Rm and Rb

\subsubsection{Order of Addition of Reagents}

The effect of order of addition of reagents was studied. From the results obtained, the optimum order of addition of reagents is as follows: $\mathrm{a}+\mathrm{b}+\mathrm{c}+\mathrm{d}$ (where $\mathrm{a}=\mathrm{Ni}^{2+}, \mathrm{b}=\mathrm{SB}, \mathrm{c}=\mathrm{NaOH}, \mathrm{d}=$ methylamine) (Figure 3.12).

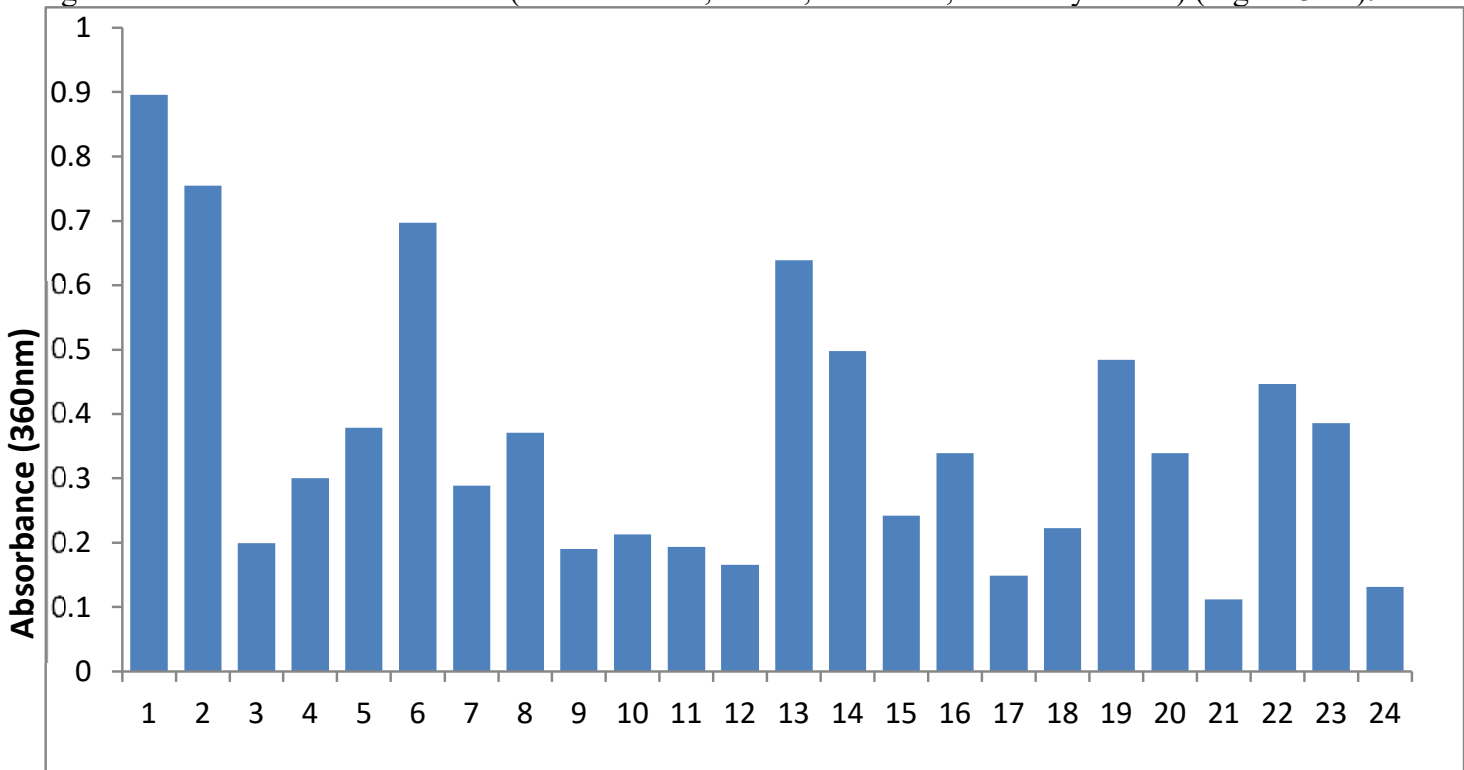

Order of addition of reagent

\subsubsection{Adherence to Beer's Law}

Figure 3.11Order of Addition of Reagent

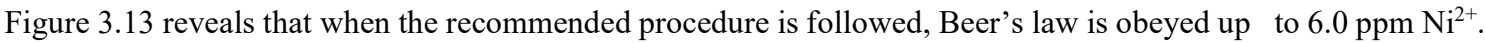
Beyond 6.0 ppm, positive deviation is observed. 


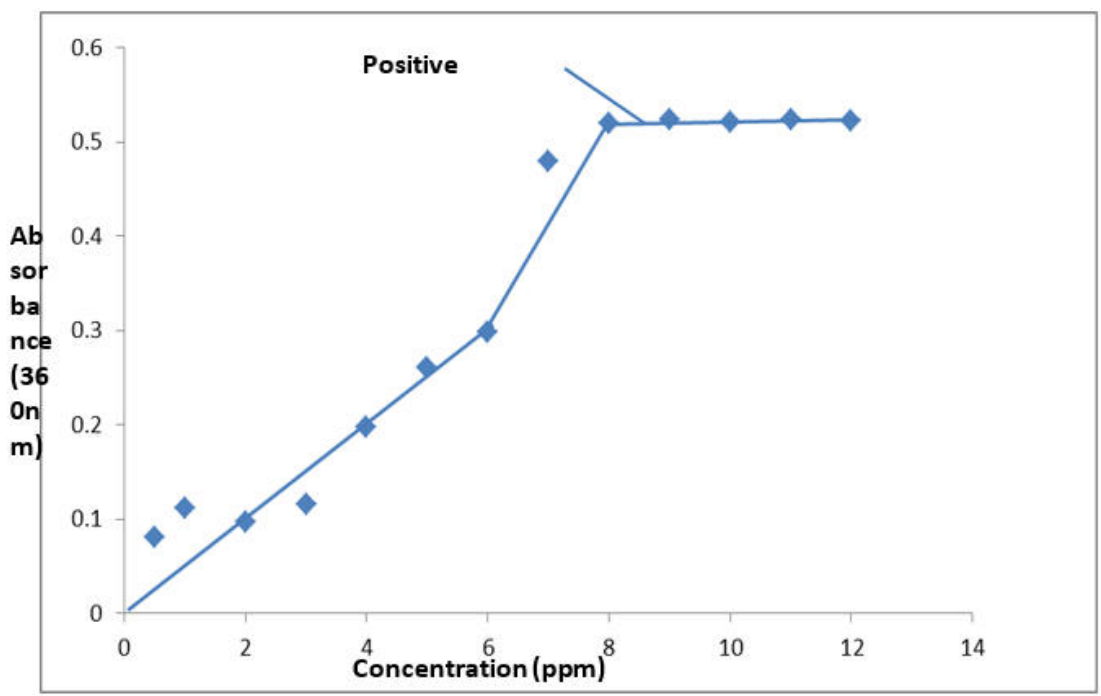

Figure 3.12 Adherence to Beer's Law

\subsubsection{Stoichiometry of the SB-Ni Complex}

Several methods can be used to determine the ratio of the ligand to the metal in a complex. In this study, Job's method of continuous variation, mole ratio and slope ratio methods were used to complement each other.

\subsubsection{Job's Method Of Continuous Variation}

The molar Absorptivity ( $\varepsilon$ ) of the $2 \times 10^{-3} \mathrm{M} \mathrm{Ni}^{2+}$ solution was calculated using the Beer-Lambert law:

$\mathrm{A}_{\left(\mathrm{Ni}^{2+}\right)}={ }_{\left(\mathrm{Ni}^{2+}\right)}$. b.c

Where $\mathrm{A}_{\left(\mathrm{Ni}^{2+}\right)}$ is the measured absorbance of the $2 \times 10^{-3} \mathrm{M} \mathrm{Ni}^{2+},{ }^{\varepsilon}\left(\mathrm{Ni}^{2+}\right)$ is the molar absorptivity of the solution, b is the path length of the cell in $\mathrm{cm}$ and $\mathrm{c}$ is the concentration of the $\mathrm{Ni}^{2+}$ ion in $\mathrm{molL}^{-1}$.

The corrected absorbances Ac, for each of the nine reaction mixtures were calculated using the relation:

$\left.\mathrm{Ac}=\mathrm{A}-\left[{ }_{(\mathrm{Ni}}^{2+}\right)(1-\mathrm{X}) \cdot \mathrm{b} \cdot \mathrm{c}\right]$

Where; $\mathrm{A}$ is the uncorrected absorbance for each of the reaction mixtures and $\mathrm{X}$ is the mole fraction of the SB. A graph of Acagainst X was plotted and the value of X was located where the extrapolated straight-line portions of the graph intersected, Figure 3.13 .

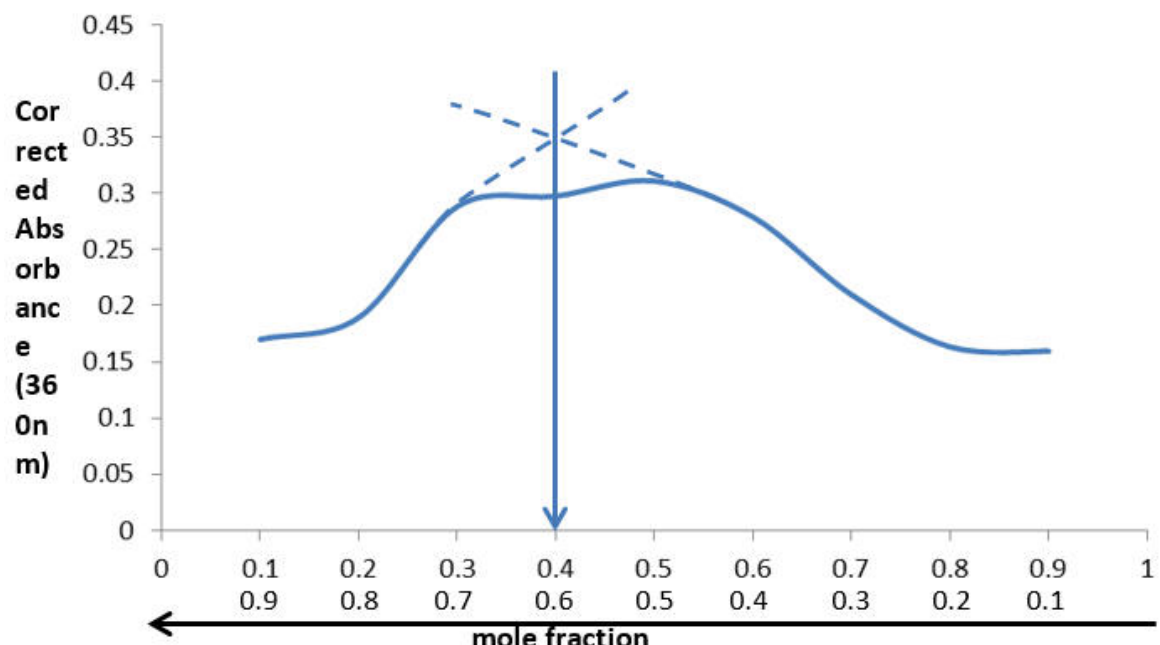

Figure 3.13 Job's plot for $\mathrm{SB}-\mathrm{Ni}^{2+}$ complex

SB-Ni complex was established by being evaluated as follows:

From Figure 3.13, the value of $\mathrm{X}$ (mole ratio of $\mathrm{SB}$ ) at the point of inflection is 0.41 and that of $\mathrm{Ni}^{2+}$ is 0.61 .

Therefore,

$X_{N i}=\frac{V_{N i}}{V_{N i}+V_{S B}}=0.41$ 
$X_{S B}=\frac{V_{S B}}{V_{S B}+V_{N i}}=0.61$

$\frac{V_{N i}}{V_{S B}}=\frac{0.41}{0.61} \approx \frac{1}{2}$

Dividing equation (3.3) by equation (3.4)

The stoichiometry of the SB-Ni complex may therfore be established as $\mathrm{NiSB}_{2}$

\subsubsection{Mole-Ratio Method}

A plot of absorbance against mole ratio, $[\mathrm{SB}] /\left[\mathrm{Ni}^{2+}\right]$, was made (Figure3.14) and the value of the mole ratio where the extrapolated straight line portions of the graph intersected was located. From Figure 3.14, the value of mole ratio at the point of inflection is 1.5 .

That is, $[\mathrm{SB}] /\left[\mathrm{Ni}^{2+}\right]=1.5 / 1 \approx 2 / 1$

The stoichiometry of the SB-Ni complex may therefore be established as $\mathrm{NiSB}_{2}$

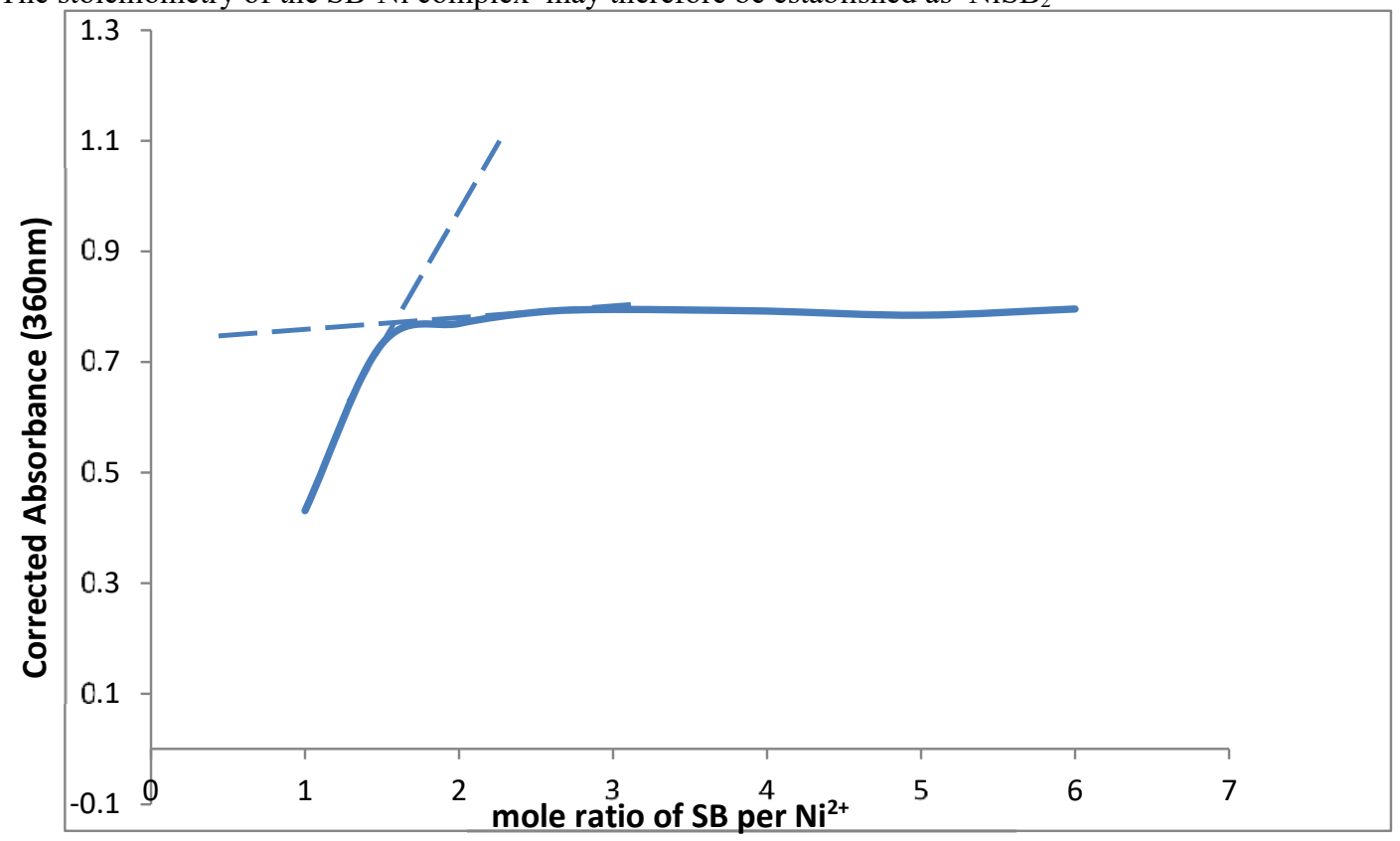

\subsubsection{Slope-ratio Method}

Figure 3.12: Mole-ratio plot for SB-Ni complex

Two sets of solution were prepared in this method; sets A and B. In set A, the concentration of the ligand was kept constant, while that of the metal ion in solution is varied, In set B, the concentration of the metal was kept constant while that of the ligand is varied.

In series A, a plot is prepared of the absorbance against concentration of metal, and in series $\mathrm{B}$, a plot was prepared of absorbance against concentration of ligand.

$$
\frac{\text { Slope } A}{\text { Slope } B} \text { gives the metal to ligand ratio }
$$




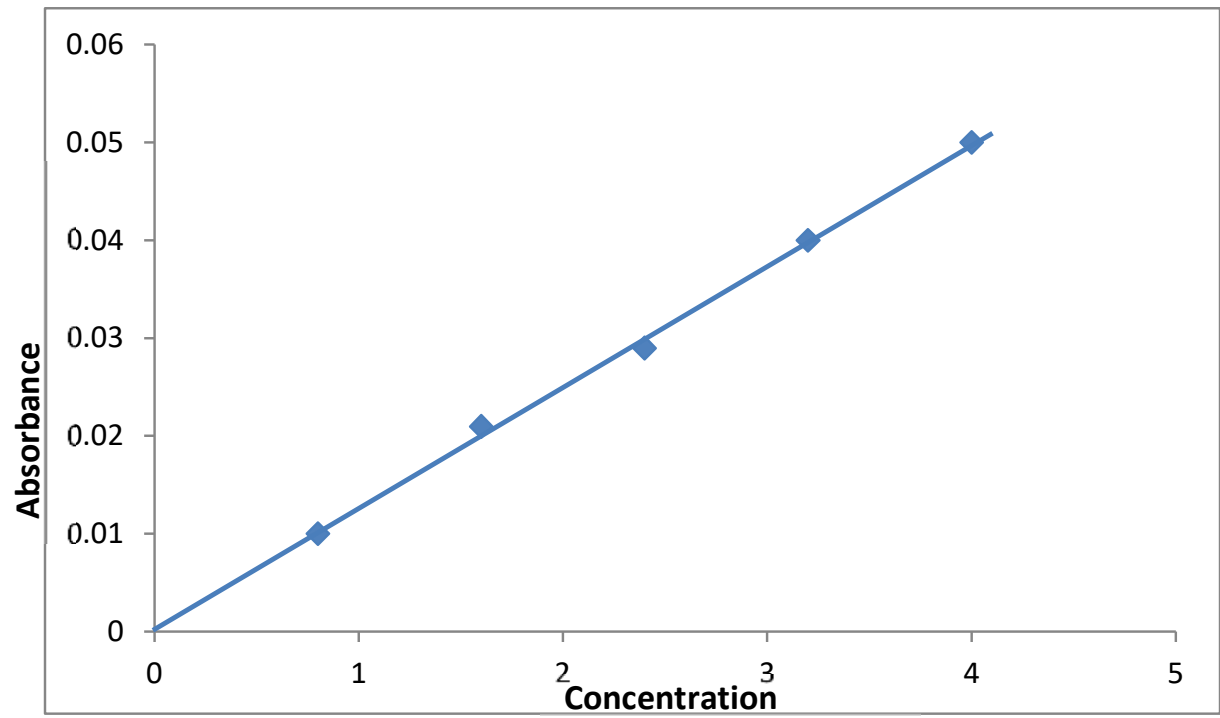

Figure 3.13: Slope Ratio Plot of Absorbance against $\mathrm{Ni}^{2+}$ for Set $\mathrm{A}$

Slope of set $\mathrm{A}=\mathbf{0 . 0 1 2 5}$

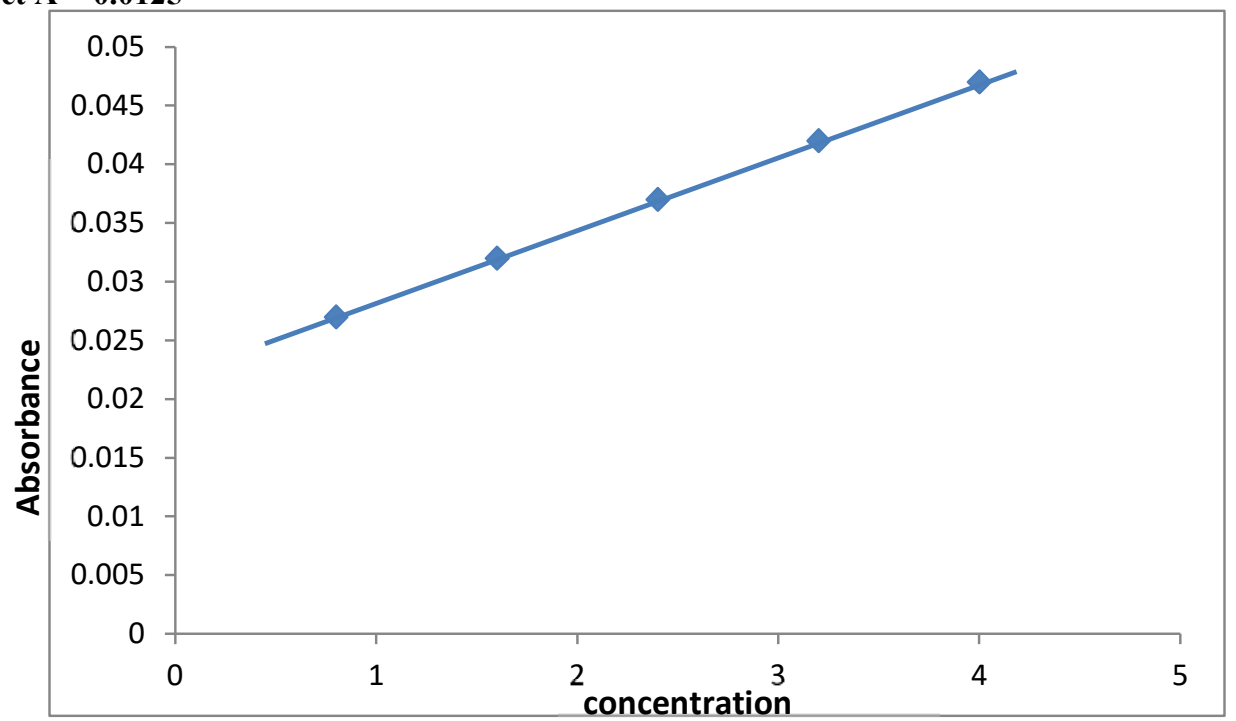

Figure 3.14: Slope Ratio Plot of Absorbance against Ligand Concentration

\section{Slope of set $B=0.00625$}

Metal to ligand ratio $=\frac{\text { slope } A}{\text { Slope } B}=\frac{0.0125}{0.00625}=\frac{1}{2}$

The three procedures, continuous variation (Job's), mole-ratio and slope-ratio methods are in agreement over the stoichiometry of the SB-Ni complex.

\subsubsection{Interference Studies}

The effect of foreign ions on the absorbance of $4.0 \mathrm{ppm}$ nickel ion concentration is shown in Table 3.2.

The criterion for interference was fixed at $\pm 0.5 \%$. That is, concentrations of foreign ions which cause relative deviations equal to, or lower than $5.0 \%$ were tolerated. Most of the ions tested were tolerated in a wide range of concentrations.

Some of the most tolerated ions are $\mathrm{Ag}^{+}, \mathrm{SO}_{4}{ }^{2-}, \mathrm{Cd}^{2+},\left(1.00 \times 10^{-1}\right.$ molL ${ }^{-1}$ max. $)$ and least tolerated ions areCa, ${ }^{+}, \mathrm{Zn}^{2+}$, $\mathrm{NO}_{3}^{-}, \mathrm{Cl}^{-}, \mathrm{CO}_{3}{ }^{2-}\left(5.00 \times 10^{-4} \mathrm{molL}^{-1} \max \right)$. 
Table 3.2: Effect of foreign ions on the absorbance of $4 \mathrm{ppm} \mathrm{Ni}^{2+}$

\begin{tabular}{cccc}
\hline Species & Added as & Tolerated conc.(molL $\left.{ }^{-1}\right)$ & Relative deviation (\%) \\
\hline $\mathrm{Ca}^{2+}$ & $\mathrm{CaSO}_{4}$ & $5 \times 10^{-4}$ & 2.9 \\
$\mathrm{Zn}^{2+}$ & $\mathrm{ZnCl}_{2}$ & $4.0 \times 10^{-2}$ & 2.5 \\
$\mathrm{Cd}^{2+}, \mathrm{SO}_{4}{ }^{2-}$ & $\mathrm{CdSO}_{4} \cdot 6 \mathrm{H}_{2} \mathrm{O}$ & $1.4 \times 10^{-4}$ & -2.63 \\
$\mathrm{Cu}^{2+}, \mathrm{Cl}^{-}$ & $\mathrm{CuCl}_{2}$ & $3.0 \times 10^{-2}$ & -2.91 \\
$\mathrm{Ag}^{+}, \mathrm{NO}_{3}{ }^{2-}$ & $\mathrm{AgNO}_{3}$ & $1.0 \times 10^{-1}$ & -3.61 \\
$\mathrm{~K}^{+}, \mathrm{CO}_{3}{ }^{2-}$ & $\mathrm{K}_{2} \mathrm{CO}_{3}$ & $5 \times 10^{-4}$ & 3.7 \\
\hline
\end{tabular}

\subsubsection{Recovery tests}

The accuracy and precision of the proposed method was studied by spiking water samples (deionized, distilled water) with nickel and analyzing five replicates of each. The results are shown below. Recovery range of 90-120 $\%$ is acceptable (Manno et al. 2006).

3.1.16 Recovery of $0.2 \mu \mathrm{g} / \mathrm{ml} \mathrm{Ni}^{2+}$ Spiked into $20 \mathrm{ml}$ Deionized, Distilled Water

The recovery of $0.2 \mu \mathrm{g} / \mathrm{ml} \mathrm{Ni}^{2+}$ added to $20 \mathrm{ml}$ deionized, distilled water, and Tables 3.3 and 3.4, show details used for the recovery calculation.

Table 3.3 Recovery of $0.2 \mu \mathrm{g} / \mathrm{ml} \mathrm{Ni}^{2+}$ Absorbance Measurements

\begin{tabular}{|c|c|c|c|}
\hline $\begin{array}{l}\text { Replicate spiked water } \\
\text { sample }\left(0.2 \mu \mathrm{g} / \mathrm{ml} \mathrm{Ni}^{2+}\right. \\
\text { added })\end{array}$ & $\begin{array}{c}\text { Absorbance } \\
\text { (360nm) }\end{array}$ & $\begin{array}{l}\text { Conc. (ppm)w.r.t. } 25 \mathrm{ml} \\
\text { final solution as read } \\
\text { from calibr. Curve }\end{array}$ & $\begin{array}{l}\text { Corresponding conc. } \\
\text { (ppm) w.r.t 20ml spiked } \\
\text { water sample }\end{array}$ \\
\hline $\mathrm{S}_{1}$ & 0.082 & 0.170 & 0.2125 \\
\hline $\mathrm{S}_{2}$ & 0.084 & 0.172 & 0.2150 \\
\hline $\mathrm{S}_{3}$ & 0.084 & 0.172 & 0.2150 \\
\hline $\mathrm{S}_{4}$ & 0.082 & 0.170 & 0.2125 \\
\hline $\mathrm{S}_{5}$ & 0.082 & 0.170 & 0.2125 \\
\hline
\end{tabular}

Table 3.4 Recovery of $0.2 \mu \mathrm{g} / \mathrm{ml} \mathrm{Ni}{ }^{2+}$ Calculations of Standard Deviation (SD), Relative Standard Deviation(RSD), 95\% Confidence Limit, and \% Recovery

$$
\begin{aligned}
& \begin{array}{cccccc}
\mathbf{S} / \mathbf{N} & \mathbf{S}_{\mathbf{i}} & \bar{s} & s_{i}^{1}-\bar{S} & \left(s_{i}-\bar{s}\right)^{2} & \sum\left(s_{i}-\bar{s}\right)^{2} \\
\hline 1 & 0.2125 & & -0.010 & 0.000100 & \\
2 & 0.2150 & & 0.015 & 0.000225 & \\
3 & 0.2150 & 0.2135 & 0.015 & 0.00225 & 0.00075 \\
4 & 0.2125 & & -0.010 & 0.0001 & \\
5 & 0.2125 & & -0.010 & 0.0001 & \\
\hline
\end{array} \\
& S D=\sqrt{\frac{\sum\left(s_{i}-\bar{s}\right)^{2}}{N-1}}=\sqrt{\frac{0.00075}{4}}=0.014 \\
& R S D=\frac{S D}{\bar{S}}=\frac{0.014}{0.2135}=0.066 \\
& 95 \% \text { confidence limit }=\bar{s} \pm t \frac{S D}{\sqrt{N}} \\
& \text { where } \mathrm{t}=2.78 \text {, from statistical table. } \\
& \therefore 95 \% \text { conf. limit }=0.2135 \pm \\
& 2.78 \times 0.014 \\
& =0.2135 \pm 0.017 \mu \mathrm{g} / \mathrm{ml} \\
& \begin{array}{l}
\% \text { Recovery }= \\
=106.75 \%
\end{array} \quad \frac{\text { amount found } \mathrm{x} 100 \%}{\text { amount added }}=\frac{0.2135}{0.2} \times 100 \%
\end{aligned}
$$

\subsubsection{Application of the SB-Ni Method}

The proposed method (SB-Ni system) was applied to the determination of $\mathrm{Ni}^{2+}$ in digested soil sample, tap water, well water and waste water. In order to further test the accuracy, results were compared with those obtained by one of the standard methods: the Atomic Absorption Spectroscopy, AAS. Table 3.5 shows that the two methods 
are in agreement.

Table 3.5: Application of SB-Ni System and AAS in the Determination of $\mathrm{Ni}^{2+}$ in Environmental Sample.

\begin{tabular}{lccc}
\hline \multicolumn{1}{c}{ Sample } & AAS & SB-Ni method \\
\cline { 2 - 4 } & $\begin{array}{c}\mathbf{2 5 m l ~ s o l n} \\
(\boldsymbol{\mu g} / \mathbf{m l})\end{array}$ & $\begin{array}{c}\text { Absorbance } \\
\mathbf{( 3 6 0 n m )}\end{array}$ & $\begin{array}{c}\text { Corresponding Conc. } \\
\boldsymbol{\mu g} / \mathbf{m l} \text { in 25ml Rm }\end{array}$ \\
\hline Digested soil sample & 2.104 & 0.202 & 1.971 \\
tap water & 0.000 & 0.004 & $\mathrm{ND}$ \\
ground water & 0.000 & 0.012 & $\mathrm{ND}$ \\
Waste water & 0.393 & 0.031 & 0.401 \\
\hline
\end{tabular}

From Table 3.2, the AAS quantified the $\mathrm{Ni}^{2+}$ ion in the soil sample as $2.104 \mu \mathrm{g} / \mathrm{ml}$ with respect to $25 \mathrm{ml}$ final sample solution while the proposed SB-Ni system registered $1.971 \mu \mathrm{g} / \mathrm{ml}$. For the wastewater sample, the AAS indicated $\mathrm{Ni}^{2+}$ ion concentration in $25 \mathrm{ml}$ sample solution as $0.393 \mu \mathrm{g} / \mathrm{ml}$, while the proposed method gave $0.401 \mu \mathrm{g} / \mathrm{ml}$. In the other water samples; tap water and ground water, both AAS and the proposed method showed no detectable $\mathrm{Ni}^{2+}$ ion in the samples. The two methods are thus in agreement.

3.1.18 Limit of Detection (LOD), Limit of Quantitation (LOQ) and Method Sensitivity (MS).

The LOD and LOQ are estimated as $0.0554 \mu \mathrm{g} / \mathrm{ml}, 0.0764 \mu \mathrm{g} / \mathrm{ml}$ respectively, as calculated from Tables 3.6 and 3.7, while MS was given as 0.0503 obtained from figure 3.12

Table 3.6: Data for the Calculation of LOD, LOQ

\begin{tabular}{|c|c|c|c|c|}
\hline $\mathbf{S} / \mathbf{N}$ & Absorbance (360nm) & $\begin{array}{l}\text { Corresponding conc. }(\mu \mathrm{g} / \mathrm{ml}) \\
\text { the original } 100 \mathrm{ml}\end{array}$ & w.r.t & $\begin{array}{l}\operatorname{Conc}(\mu \mathrm{g} / \mathrm{ml}) w . r . t \text { the final } \\
25 \mathrm{ml}\end{array}$ \\
\hline 1 & 0.021 & 0.250 & & 0.050 \\
\hline 2 & 0.022 & 0.250 & & 0.050 \\
\hline 3 & 0.022 & 0.250 & & 0.050 \\
\hline 4 & 0.022 & 0.250 & & 0.050 \\
\hline 5 & 0.019 & 0.220 & & 0.044 \\
\hline 6 & 0.019 & 0.220 & & 0.044 \\
\hline 7 & 0.019 & 0.220 & & 0.044 \\
\hline 8 & 0.019 & 0.220 & & 0.044 \\
\hline 9 & 0.019 & 0.220 & & 0.044 \\
\hline 10 & 0.019 & 0.220 & & 0.044 \\
\hline
\end{tabular}

Table 3.7: Derived Data for the Calculation of LOD, LOQ and MS

\begin{tabular}{lllll}
\hline $\mathbf{S}_{\mathbf{S}}$ & $\bar{S}$ & $S_{i}-\bar{S}$ & $\left(s_{i}-\bar{S}\right)^{2}$ & $\sum\left(s_{i}-\bar{S}\right)^{2}$ \\
\hline 0.050 & & 0.0036 & $1.296 \times 10^{-5}$ & \\
0.050 & & 0.0036 & $1.296 \times 10^{-5}$ & \\
0.050 & & 0.0036 & $1.296 \times 10^{-5}$ & \\
0.050 & & 0.0036 & $1.296 \times 10^{-5}$ & \\
0.044 & 0.0464 & 0.0024 & $5.76 \times 10^{-6}$ & \\
0.044 & & 0.0024 & $5.76 \times 10^{-6}$ & $8.64 \times 10^{-5}$ \\
0.044 & & 0.0024 & $5.76 \times 10^{-6}$ & \\
0.044 & 0.0024 & $5.76 \times 10^{-6}$ & \\
0.044 & & 0.0024 & $5.76 \times 10^{-6}$ & \\
0.044 & & 0.0024 & $5.76 \times 10^{-6}$ & \\
\hline
\end{tabular}

$$
\begin{aligned}
& \delta=\sqrt{\frac{\sum\left(s_{i}-\bar{s}\right)^{2}}{N-1}}=\sqrt{\frac{8.64 \times 10^{-5}}{9}}=\sqrt{9.6 \times 10^{-6}}=0.003 \\
& \mathrm{LOD}=\bar{s}+3 \delta= \\
& =0.0464+3(0.003) \\
& =0.0554 \mu \mathrm{g} / \mathrm{ml} \\
& \mathrm{LOQ}=\bar{s}+10 \delta \\
& =0.0464+10(0.003) \\
& =0.0764 \mu \mathrm{g} / \mathrm{ml}
\end{aligned}
$$




\section{Calculation of MS}

$$
\text { MS = slope of Figure } 3.12=\frac{\Delta A}{\Delta c o n c .}=\frac{0.201}{4}=0.0503
$$

\section{CONCLUSION}

Schiff bases are among the most widely used ligands due to their facile synthesis, remarkable versatility and good solubility in common solvents. Thus, they have played an important role in the development of coordination chemistry, as they readily form stable complexes with most of the metals. The spectroscopic determination of metals using Schiff base metal complex is very important in analytical chemistry. This would be a veritable contribution to solving environmental problems associated with toxic metals (Ni). This study helped to establish a novel, simple and cheap analytical method for the determination of nickel in an environmental media especially in developing countries where the cost and maintenance of sophisticated instruments are extremely high. In this study, Schiff base ligand was synthesized using benzaldehyde and aniline to form a metal complex with the target analyte $\left(\mathrm{Ni}^{2+}\right)$. The synthesized ligand and its $\mathrm{Ni}$ complex were characterized using nuclear magnetic resonance (NMR),GC-MS, melting point determination, electrical conductivity, IR, and UV-VIS spectroscopic techniques. The stoichiometry of the Schiff base-Ni complex was established using Job's method of continuous variation, mole- ratio and slope-ratio methods.

\section{REFERENCES}

Al-Resayes, S. I., Shakir, M., Shahid, N., Azam, M. and Khan, A. U. (2011). Synthesis, Spectroscopic Characterization and In-vitro Antimicrobial Studies of Schiff base Ligand, H2L Derived from Glyoxalic acid and 1,8 diaminonaphthalene and its $\mathrm{Co}$ (II), Ni (II), Cu (II) and Zn (II) complexes. Arab Journal of Chemistry. 2: $1-9$.

Amit, R. Y., Vijaya, V. D., Gaurav, B. P. and Anand S. A. (2014). Synthesis, Characterization,Biological and Electrical Conductivity Studies of some Schiff Base Metal Complexes. Bulletin of Chemical Society of Ethiopia. 28(2): 255-264.

Anand, P., Patil, V. M., Sharma, V. K, Khosa, R. L and Masand, N. (2012). Schiff bases: A Review on Biological Insights. International Journal of Drug Discovery 3(3): 851-68.

Anita, S. and Manish, S. (2013). Synthesis and Characterization of Some Transition Metal Complexes Derived from Bidentate Schiff Base Ligand. Journal Applied. Chemistry. 3:62-66.

Annapoorani, S. and Krishnan, C. (2013). Synthesis and Spectroscopic Studies of Ttrinuclear N4 Schiff Base Complexes International Journal of Chemical Technology Research. 5 (1): 180-185.

Archana, S. (2013). Synthesis and Characterization of Schiff base Salicylaldehyde and Thiohydrazones and its Metal Complexes. Advanced Applied Science Research. 4(4): 152-154.

Badekar R. R., Kulkarni S. W., Lokhande R. S. and Thawkar B. S. (2016). Synthesis, Characterization and Antibacterial Activity of Hydrazonyl Derivative of $\alpha$-Benzilmonoxime Ligand and its Iron (III), Chromium (III) and Ruthenium (III) metal complexes. International Journal of Applied Research; 2(9):175-179.

Chandraleka, S., Chandramohan, G., Dhanasekaran, D., Meenakumari, P. and Panneerselvam, A. (2011) Antifungal Activity of Amino acid Schiff base Copper (II) Complexes with Phenanthroline and Bipyridyl. International Journal of Chemical Analytical Science.2(10): 1235-40.

Chaudhary, N. K. (2013). Synthesis and Medicinal use of Metal Complexes of Schiff bases. BIBECHANA. 9: 75 80.

Consiglio, G., Failla, S., Finocchiaro, P., Oliveri, I. P and Di Bella, S. (2012) An Unprecedented Structural Interconversion in Solution of Aggregate Zinc(II) Salen Schiff-Base Complexes. Inorg. Chem., 51: 84098418 .

Ekoko, O. P. (2014). Algebra, Trignometry and Calculus, Fourth Edition, Pp 125-144.

Garima, Y and Jyoti, V. M. (2015). Green Synthesis of Schiff Bases by Using Natural Acid Catalysts. International Journal of Science and Research. 4(2): 121-127.

Gobonka, I., Kawacki, A. and Musial, W. (2015). Stability Studies of a Mixture of Paracetamol and Ascorbic Acid Prepared Extempore at Elevated Temperature and Humidity Conditions. Tropical Journal of Pharmaceutical Research.14(8):1315-1321.

Katwal, R., Kaura, H and Kapur, B. K. (2013). Applications of Copper-Schiff's Base Complexes: Scientific Reviews \& Chemical Communications. 3 (1): 1-15.

Manno, E., Varrica, d. And Dongarra, G. (2006). Metal Distribution in Road Dust Samples Collected in an Urban Area close to a Petrochemical Plant at Gela, Sicily. Atmosphere Environment, 40: 5929-5941.

Mtunzi, F. M., Dikio, E. D and Moja, S. J. (2015). Evaluation of heavy metal Pollution on Soil in Vaderbijlpark, South Africa. International Journal of Environmental Monitoring and analysis. 3(2): 44-49.

Okolo, P.O. and Okuo, J.M. (2003). Spectrophotometric Determination of Ammonium-Nitrogen with Quinol in 
Aqueous Medium. Global Journal of Pure and Applied Sci. 9 (4):490-502.

Okoye, C. O., Chukwuneke, A. M., Ekere, N. R. and. Ihedioha, J. N (2013). Simultaneous Ultraviolet-visible (UVVIS) Spectrophotometric Quantitative Determination of $\mathrm{Pb}, \mathrm{Hg}, \mathrm{Cd}$, as and $\mathrm{Ni}$ ions in Aqueous Solutions using Cyanidin as a Chromogenic Reagent. International Journal of Physical Sciences vol. 8(3): 98-102 .

Raman, N., Joseph, J., Sathivel, A. and Jeyamurugan, R. (2009). Synthesis, Structural Characteristic and Antimicrobial Studies of Novel Schiff Base Copper (II) Complexes Journal of Chilean Chemical Society. 54(4):354-358.

Singh, K., Kumar, Y., Puri, P., Sharma, C. and Aneja, K. R. (2012). Thermal, Spectral, Fluorescence and Antimicrobial of Cobalt, Nickel, Copper and Zinc Complexes Derived from 4-[(5- Bromo-Thiphen-2ylmethylene)-amino]-3-mercapto-6-methyl-5-oxo-\{1, 2, 4] triazines. International Journal of Inorganic Chemistry. 12: 1-9.

Skoog, A.D., West, M.D., Holler, F.J. and Crouch, R.S. (2007): Fundamentals of Analytical Chemistry. $8^{\text {th }}$ Edition. p82. 